\title{
PROVING A CRIMINAL PREDISPOSITION: SEPARATING THE UNWARY INNOCENT FROM THE UNWARY CRIMINAL
}

\author{
W.H. JOHNSON, III $\dagger$
}

\section{INTRODUCTION}

The American criminal justice system is founded on the belief that every man is responsible for his own conduct and therefore should be held accountable for the acts he commits of his own free will. ${ }^{1}$ The entrapment defense furthers these goals by shielding from prosecution those defendants who were not predisposed to commit the criminal act but committed the crime only because of government imducement. ${ }^{2}$ The question of predisposition is thus dispositive in an entrapment defense.

The following scenarios represent two classic examples of a government sting operation: one, a successful operation in which the government obtains a conviction; the other, an operation in which the government fails to obtain a conviction because the defendant successfully asserts the defense of entrapment.

Scenario 1: $\mathrm{X}$ has two prior convictions, one for possession of heroin with the intent to sell and one for possession of cocaine. In addition, $X$ has recently been acquitted of the charge of possession of a controlled substance. He is approached by $\mathrm{Y}$, a wellknown crack wholesaler. $Y$ offers to sell crack to $X$. $X$ agrees to buy a significant amount of crack froin $\mathrm{Y}$, stating that he, $\mathrm{X}$, can

$\dagger$ This Note is dedicated to my parents, whose love and support have made my education possible.

1. See R.A. Duff, Intention, Agency and Criminal liability 8 (1990) ("A defendant is guilty of a criminal offense only if he committed its actus reus with the appropriate mens rea: he can avoid conviction by admitting that he actually committed the actus reus of the offense ...b by] offering an excuse which shows he lacked the requisite mens rea ....").

2. As one commentator has said, "The federal [entrapment] defense has the virtue of focusing upon the culpability of the defendant. It attempts to distinguish between persons who are blameworthy and persons who are not. In the absence of extraordinary circumstances, that should be the goal of our [criminal laws]." Roger Park, The Entrapment Controversy, 60 MINN. L. REv. 163, 271 (1976). 
make a lot of money by retailing the crack on the street. At the agreed time and place, $\mathrm{X}$ gives $\mathrm{Y}$ cash and in return receives the specified amount of crack. Government agents immediately appear and arrest $\mathrm{X}$.

Scenario 2: $\mathrm{X}$ has no prior convictions but lives in a neighborhood that is notorious for its many crack houses and drug dealers. X knows many of these drug dealers personally. $Y$ approaches $X$ and asks $X$ to sell him some crack. $X$ refuses. $Y$, over a period of several days, continually calls $X$ at home in an attempt to convince $\mathrm{X}$ that $\mathrm{Y}$ is in desperate need of crack to help his sister through withdrawal pains. After a week of hearing Y's mcreasingly desperate pleas for his sister, $\mathrm{X}$ buys a small amount of crack from a local dealer and sells it to $\mathrm{Y}$ at cost. $\mathrm{Y}$ immediately places $\mathrm{X}$ under arrest.

In both scenarios, $\mathrm{X}$ is likely to assert an entrapment defense due to the government's use of a sting operation. In Scenario 1 , the government will introduce evidence of X's prior convictions, his recent arrest on the charge of possession of a controlled substance, lis eagerness to engage in the illegal activity, and his intention to profit from the illegal activity to show that $\mathrm{X}$ was predisposed to commit a drug-related offense. Given this evidence, it is probable that $\mathrm{X}$ will be found guilty because the government did not entrap him; it merely provided him with an opportunity to commit the crime. In Scenario 2, there is no evidence to indicate that $\mathrm{X}$ had any criminal predisposition to commit a drug-related offense. It is therefore likely that $X$ will be able to prove that the government entrapped him and will be acquitted.

Evidentiary issues have been the dommant focus of federal court decisions regarding the entrapment defense simce the U.S. Supreme Court first recognized the vahitity of such a defense. When a defendant claims that he committed the criminal act only because of government inducement, the governinent is allowed to introduce evidence that indicates that before the government offered the defendant an inducement, the defendant had a pre-existing propensity to commit the crime with which he is charged. Evidence that the defendant has engaged in conduct similar to the charged offense-especially a prior conviction on the saine charge-strongly suggests that the defendant was predisposed to commit the crime and therefore was not entrapped. Evidence that the defendant responded eagerly to the government's inducement is powerful evidence that he was predisposed to commit the crimi- 
nal act when an opportunity presented itself; conversely, the defendant's reluctance to engage in the criminal conduct indicates that he was not predisposed. The defendant's reputation also is admissible to prove a predisposition because it is unlikely that a community will falsely perceive an innocent individual as one who engages in criminal activity. Because unany crimes require either specialized knowledge or criminal contacts that ordinary individuals do not possess, the defendant's ability to perform the illegal act without difficulty is evidence that the defendant was predisposed. Finally, the fact that the defendant intended to profit froin the illegal transaction is strong evidence that this profit, not the government inducement, inotivated the defendant to commit the crime.

Critics argue that the introduction of inuch of this evidence is unfair to the defendant. These critics contend that the jury may use evidence of the defendant's similar conduct and reputation not to determine the defendant's predisposition but to determine that he committed the offense charged. ${ }^{3}$ Such an argument lacks inerit because by asserting an entrapinent defense, a defendant admits that he committed the prohibited conduct but alleges that he did so only as a result of the government's inducement. The question of whether the defendant actually committed the offense is therefore seldoin at issue. Critics also allege that the defendant's subsequent similar conduct is irrelevant to the predisposition inquiry because the defendant's inental state may change over time. ${ }^{4} \mathrm{Al}-$ though it is true that mental states may change over time, it is also true that an individual who commits a crime solely because the government induced him to do so is unlikely to continue to engage in such acts once the mducement is removed. By continuing to engage in such conduct, the defendant indicates a pre-existing propensity to engage in that conduct.

This Note serves two distmct functions. First, it presents a coinprehensive review of the types of evidence that may be used to prove that a defendant was predisposed to commit the charged offense and that therefore he was not entrapped. Second, it analyzes the contentions of critics of various evidentiary rules that have an effect on the predisposition inquiry. Part I examimes the developinent of the entrapment defense in the U.S. Supreme

3. See infra notes $145-46,178-79$ and accompanying text.

4. See infra notes $\mathbf{1 7 2 - 7 4}$ and accompanying text. 
Court, particularly the Court's determination that the entrapment defense exists to protect from prosecution ouly those defendants who were not predisposed to engage in the prohibited conduct. Part II describes the types of evidence that may be used to prove the defendant's predisposition. Part III examines the contentions of critics who advocate the exclusion of inany of the types of evidence discussed in Part II and determines that these contentions are without merit. This Note concludes that the current evidentiary rules accurately and fairly distinguish those defendants who are predisposed from those who are not, thus effectuating the public policy goal of the entrapment defense.

\section{The ENTRAPMENT Defense IN THE U.S. SuPREME COURT}

Since the entrapinent defense was first formulated, there has been an intense debate over what public policy goals the defense should serve. Advocates of the subjective view of the defense beheve that "Congress could not have intended criminal punishment for a defendant who has committed all the elements of a proscribed offense, but was induced to commit them by the Government." The subjective defense therefore focuses on whether the individual defendant was predisposed to commit the crime before the government inducement. If the defendant was predisposed, then the government's inducement was not responsible for the defendant's criminal conduct, and the defendant sliould be held accountable for his criminal conduct because he was not entrapped.

Advocates of an objective entrapment defense believe that the defense sliould focus on the conduct of the government and its agents. Under this view of the defense, entrapment would exist if the government engaged in conduct that was illegal or improper. ${ }^{6}$ The defendant's predisposition would be irrelevant. As advocates of the subjective defense note, however, an objective defense would exonerate defendants who intentionally committed crimes merely because the government was involved in some way in the criminal enterprise.

5. United States v. Russell, 411 U.S. 423,435 (1973).

6. Sherman v. United States, 356 U.S. 369, 382 (1958) (Frankfurter, J., concurring).

7. See Russell, 411 U.S. at $434-35$. 
A majority of the U.S. Supreme Court has always held that the entrapment defense is subjective. ${ }^{8}$ The Court first recognized the existence of a federal entrapment defense in Sorrells $v$. United States. ${ }^{9}$ In Sorrells, a prohibition agent asked the defendant to obtain whiskey for him, but the defendant refused the agent's request several times. The agent finally convinced Sorrells to procure the illegal liquor by playing on his sympathy as an old war buddy. Sorrells was convicted of possessing and selling alcohol in violation of the National Prohibition Act (popularly known as the Volstead Act). ${ }^{10}$ The Supreme Court reversed the conviction and remanded the case for a new trial, holding that entrapinent was a valid defense and that the issue should have been subimitted to the jury. ${ }^{11}$

Although the Justices agreed that entrapment was a valid defense, they split over the foundation of the defense. The majority favored a subjective view of entrapment, focusing on whether the defendant was predisposed to commit the crime; the concurrence favored an objective view. The majority believed that entrapment exists "when the criminal design originates with the officials of the Government, and they implant in the mind of an innocent person the disposition to commit the alleged offense and induce its commission in order that they may prosecute." ${ }^{\text {"If }}$ If the defendant was predisposed, the government did nothing more than present an opportumity to one who was already likely to engage in the criminal activity. If the defendant was not predisposed, the defendant would not have committed the crime but for the government's imducement. The majority determined that the correct test for determining the existence of a criminal predisposition was a subjective evaluation of the defendant's mental state. Government inducement was not enough, by itself, to prove entrapment. ${ }^{13}$

8. See infra notes $12-13,17-19,25-26$ and accompanying text.

9. 287 U.S. 435 (1932).

10. National Prohibition (Volstead) Act, ch. 85, tit. II, § 3, 41 Stat. 305, 308-09 (1919), repealed by U.S. CONST. amend. XXI.

11. Sorrells, 287 U.S. at 452 . Entrapment is normally a question for the jury. If, however, the prosecution is unable to offer sufficient admissible evidence of the defendant's predisposition, the court may find that the defendant was entrapped as a matter of law. See Jacobson v. United States, 112 S. Ct. 1535, 1543 (1992).

12. Sorrells, 287 U.S. at 442.

13. As the majority explamed,

[T] he defense of entrapment is not simply that the particular act was committed at the instance of government officials. That is often the case where the proper action of these officials leads to the revelation of criminal enterprises. The 
Justice Roberts, in a concurring opinion, strongly disagreed with the niajority as to the basis of the entrapnient defense. $\mathrm{He}$ argued that "[t]he applicable principle is that courts nuust be closed to the trial of a crime instigated by the government's own agents," ${ }^{14}$ suggesting that the entrapinent defense should focus on the government's conduct, not the defendant's character. ${ }^{15} \mathrm{Al}$ though the concurrence suggested that the government's conduct should be the basis of an entrapnent defense, it failed to suggest a test or standard to define entrapinent. It was Justice Frankfurter, writing the concurring opinion in Sherman $v$. United States, ${ }^{16}$ the next major Supreme Court case dealing with the entrapment defense, who first articulated a complete version of the objective view of the defense.

In Sherman, a government informant, who was being treated for a narcotics addiction, convinced the defendant, who was also being treated for a narcotics addiction, to procure a supply of narcotics for hin. The defendant reluctantly agreed to the informant's request only after several refusals and then only when the informant claimed that he was suffering severe withdrawal pains. Once again, a five-Justice majority evaluated the defendant's mental state under the subjective test: "To deternine whether entrapment has been established, a line must be drawn between the trap for the unwary innocent and the trap for the unwary criminal." ${ }^{\text {"T }}$ The nuajority looked to the defendant's initial reluctance to procure the drugs, the multiple pleas of the supposedly suffering inforinant, and the fact that Slierman niade no profit on the sale to determine that entrapment existed as a nuatter of

predisposition and criminal design of the defendant are relevant.... [I]f the defendant seeks acquittal by reason of entrapment he cannot complaim of an appropriate and searching inquiry into his own conduct and predisposition as bearing upon that issue.

Id. at 451 (citation omitted).

14. Id. at 459 (Roberts, J., concurring)

15. Justice Roberts felt that an analysis of the defendant's character was inappropriate in an entrapment defense.

To say that [the instigation and inducement of a crime] by an official of government is condoned and rendered innocuous by the fact that the defendant has a bad reputation or had previously transgressed is wholly to disregard the reason for refusing the processes of the court to consummate an abhorrent transacId. tion.

16. 356 U.S. 369 (1958).

17. Id. at 372 . 
law. ${ }^{18}$ In answer to the concurrence's argument for the objective view of entrapment, the majority noted that government inducement of a crime was sometimes necessary to prosecute criminals and that an objective test would place an "obvious handicap" on the prosecution. ${ }^{19}$

Justice Frankfurter argued that the entrapment defense should be an objective evaluation of the government's conduct in the course of the investigation. ${ }^{20}$ Under this standard, entrapinent would exist if the police enforced the law "by lawless means or means that violate rationally vindicated standards of justice."21 If the conduct of the police was acceptable, the defendant would be guilty, but if it was not, the defendant would be acquitted because he had been entrapped. The concurrence would not look to the predisposition of the defendant because "[n]o matter what the defendant's ... present inclinations to criminality, ... certain police conduct ... is not to be tolerated by an advanced society."22

The Supreme Court reaffirmed the subjective view of the entrapment defense in United States $v$. Russell, ${ }^{23}$ a case that presented a greater level of government involveinent than any prior entrapment case the Court had decided. In Russell, an undercover agent approached a suspected drug manufacturer and offered to provide him with a drug that was difficult to obtain and that was a vital ingredient in the production of methamphetamine (speed). In exchange, the manufacturer was to give the agent one-half of the resulting drug. After the transaction was consummated, Russell

18. Id. at 373 .

19. Id. at 376-77. Undercover operations are often used to unearth so-called "victimless" crimes, such as prostitution, illegal drug sales, and loan sharking, as well as crimes against the public, such as bribery of public officials and price fixing. Such undercover operations are necessary because these two classes of crimes do not produce victins who are willing to report the crime to the police. See generally Gerald Dworkin, The Serpent Beguiled Me and I Did Eat: Entrapment and the Creation of Crimes, 4 LAW AND PHIL. 17, 18 (1985) (discussing crimes that produce no complaining witnesses).

20. "The crucial question, not easy of answer, to which the court must direct itself is whether the police conduct revealed in the particular case falls below standards, to which common feelings respond, for the proper use of governmental power." Sherman, 356 U.S. at 382 (Frankfurter, J., concurring).

21. Id. at 380. Since the objective view of entrapment never garnered the support of a majority of the Supreme Court, there are no federal cases that elaborate on what actions "violate rationally vindicated standards of justice." Id.

22. Id. at 382-83.

23. 411 U.S. 423 (1973). 
was arrested and convicted of several drug violations. The U.S. Court of Appeals for the Ninth Circuit reversed the conviction due to "an intolerable degree of governmental participation in the criminal enterprise." ${ }^{24}$ The Supreine Court reversed the Ninth Circuit's decision and expressly refused to replace the subjective view of entrapinent with the objective view. ${ }^{25}$ The Court's decision was based, in part, on the public policy rationales favoring the use of undercover operations. ${ }^{26}$

The dissenting Justices would have affirmed the Ninth Circuit's decision reversing the conviction. In his dissent, Justice Stewart traced the history of the objective view of the entrapinent defense and argued that it should be adopted because "the Government cannot be permitted to instigate the commission of a criminal offense in order to prosecute someone for committing it." ${ }^{27}$ The dissent highlighted the risks of using a predisposition inquiry: "[F]ocusing on the defendant's innocence or predisposition has the direct effect of making what is permissible or inpermissible police conduct depend upon the past record and propensities of the particular defendant involved."28 Justice Stewart argued that the government's actions in supplying the defendant with an ingredient that was difficult to obtain constituted impermissible police conduct and that the defendant had been entrapped as a matter of law. ${ }^{29}$

Although the vast inajority of academics and student commentators favor the objective approach, ${ }^{30}$ the subjective approach has

24. United States v. Russell, 459 F.2d 671, 673 (9th Cir. 1972), rev'd, 411 U.S. 423 (1973).

25. "[I]t [does not] seen particularly desirable for the law to grant complete immunity from prosecution to one who himself planned to commit a crime, and then committed it, sunply because government undercover agents subjected him to inducements which might have seduced a hypothetical individual who was not so predisposed." Russell, 411 U.S. at 434.

26. The Court noted that some crimes could be detected ouly by undercover operations.

In order to obtain convictions for illegally manufacturing drugs, the gathering of evidence of past unlawful conduct frequently proves to be an all but unpossible task. Thus, im drug-related offenses, law enforcement persounel have turned to one of the only practicable means of detection: the infiltration of drug rings and a limited participation in their unlawful present practices. Such infiltration is a recognized and permissible means of investigation ....

Id. at 432.

27. Id. at 439 (Stewart, J., dissenting).

28. Id. at 443 .

29. Id. at $446-49$.

30. See, e.g., Richard C. Donnelly, Judicial Control of Informants, Spies, Stool Pi- 
become firmly entrenched in the federal courts. The objective approach achieved its highest level of support on the Court im Sherman and Russell $l^{31}$ but lost support in later cases. Justice Brennan, who argued for the objective view in both Sherman and Russell, nevertheless concurred with the majority's use of the subjective formulation in Mathews $v$. United States. ${ }^{32}$

I write separately only because I have previously joined or written four opimons dissenting from this Court's holdings that the defendant's predisposition is relevant to the entrapment defense .... . Were I judging on a clean slate, I would still be mclined to adopt the view that the entrapment defense should focus exclusively on the Government's conduct. But I am not writing on a clean slate; the Court has spoken definitively on this point. Therefore I bow to stare decisis, and today join the judgment and reasoming of the Court. ${ }^{33}$

In the most recent Supreme Court case dealing with entrapment, none of the Justices advocated the use of the objective method. ${ }^{34}$

\section{Proving PREdisposition}

Under the subjective view of the entrapment defense, proof of a defendant's criminal predisposition is central to the determination of entrapment. Predisposition is defined as a "defendant's inclination to engage in illegal activity for which he has been charged, i.e., that he is ready and willing to coinmit the crime." 35 To determine whether a defendant possessed the requisite predis-

geons, and Agent Provocateurs, 60 YALE L.J. 1091, 1114 (1951) ("The inquiry should be directed solely to the propriety of the officer's conduct."); Jerry Schreibstein, Note, Entrapment in Light of Mathews v. United States: The Propriety of Inconsistency and the Need for Objectivity, 24 U.S.F. L. REV. 541, 545 n.31 (1990) (citing commentators who advocate the adoption of an objective entrapment defense).

31. In Sherman, four Justices signed the concurring opinion favoring the objective approach. See Sherman v. United States, 356 U.S. 369, 378 (1958). In Russell, a total of four Justices dissented, arguing that the government's conduct constituted entrapment, the defendant's predisposition notwithstanding. Russell, 411 U.S. at 436, 439.

32. 485 U.S. 58 (1988) (holding that a defendant has the right to claim the defense of entrapment and simultaneously deny one of the elements of the crime, despite the fact that the two claims are inconsistent).

33. Id. at $66-67$ (Breman, J., concurring) (citations omitted).

34. Jacobson v. United States, 112 S. Ct. 1535 (1992) (holding that evidence of defendant's similar noncriminal conduct is insufficient, by itself, to prove that the defendant was predisposed to commit the crime).

35. BLACK'S LAW DICTIONARY 1177 (6th ed. 1990). 
position to commit the alleged offense, most courts look to the totality of the circumstances. ${ }^{36}$ This Part examines various types of evidence that prosecutors are allowed to present to show the defendant's criminal predisposition.

\section{A. Defendant's Similar Conduct}

Short of an admission, the easiest way for the prosecution to prove that a given defendant had the necessary predisposition to commit an offense is to demonstrate that the defendant has engaged in similar acts. These acts may have occurred either before or after the offense for which the defendant is being tried. In addition, these acts may be either legal or illegal, as long as they are similar to the crime with which the defendant is being charged.

1. Prior Criminal Acts. Evidence of the defendant's prior similar criminal acts is admissible to prove the defendant's predisposition to commit the crime. ${ }^{37}$ As long as the defendant's prior criminal act was committed without any government inducement, evidence of such acts strongly indicates that the government did not entrap him. Such evidence is appropriately used to refute the defendant's assertion that he was entrapped.

The use of this type of information is not uncontestable, however. Under Rule 404(b), ${ }^{38}$ evidence of a defendant's prior criminal acts must be excluded when it is used only to convince the jury that the defendant's character was such that he was likely to

36. Paul Marcus, The EnTRapment Defense $\S 4.12$ (1989).

37. See, e.g., United States v. Stenberg, 803 F.2d 422, 432 (9th Cir. 1986) ("Evidence of prior criminal acts . . . is adnissible to show predisposition where the defense of entrapment is raised."); United States v. Manzella, 782 F.2d 533, 546 (5th Cir.) ("Extrinsic evidence of prior crimes is logically relevant in resolving this issue because it suggests [defendant]'s predisposition to commit [the crime] regardless of government influence."), cert. denied, 476 U.S. 1123 (1986); United States v. Blankenship, 775 F.2d 735, 739 (6th Cir. 1985) ("The introduction of evidence of extrinsic offenses is a reliable method of proving the criminal predisposition needed to rebut the allegation or inference of entrapment.") (quoting United States v. Salisbury, 662 F.2d 738, 741 (11th Cir. 1981), cert. denied, 457 U.S. 1107 (1982)).

38. The rule provides:

Evidence of other crimes, wrongs, or acts is not admissible to prove the character of a person in order to show action in conformity therewith. It may, however, be admissible for other purposes, such as proof of motive, opportunity, intent, preparation, plan, knowledge, identity, or absence of mistake or accident ....

FED. R. EVID. 404(b). 
commit a crime..$^{39}$ As a result, defendants routinely claim that their prior criminal acts are inadinissible. When a defendant claims entrapment, however, the prosecution must prove that the defendant did possess a propensity to commit such crimes to rebut the defendant's entrapment defense.

There is a fine distinction between using prior criminal acts to prove that the defendant acted in conformity with his character and using such acts to show a predisposition to commit the crimie. As the Court explained in United States v. Burkley, ${ }^{40}$ the government may properly introduce evidence of the defendant's prior criminal acts to show that the defendant had a propensity to commit such crimes when a defendant raises an entrapınent defense, but such evidence is inadmissible if the government attempts to use it to prove that the defendant committed the charged offense as a result of his propensity. ${ }^{41}$ In holding that the defendant's prior criminal acts could be admitted to prove his predisposition, the court noted that any prejudice that a defendant suffers from the introduction of this evidence is a direct result of the defendant's decision to invoke the entrapment defense. ${ }^{42}$

To avoid any undue prejudice to the defendant, courts often restrict the types of prior offenses that may be introduced into evidence to prove a predisposition. These restrictions further guarantee that the evidentiary rules will advance the policy goals of the entrapment defense, separating those defendants who were

39. Courts are usually careful to exclude evidence of prior crimes when it is used for this purpose. In Michelson v. United States, 335 U.S. 469 (1948), the Supreme Court stated the general rule and its rationale.

The state may not show defendant's prior trouble with the law, specific criminal acts, or ill name among his neighbors, even though such facts might logically be persuasive that he is by propensity a probable perpetrator of the crime. The inquiry is not rejected because character is irrelevant; on the contrary, it is said to weigh too much with the jury and to so overpersuade them as to prejudge one .... The overriding policy of excluding such evidence, despite its adinitted probative value, is the practical experience that its disallowance tends to prevent confusion of issues, unfair surprise and undue prejudice. Id. at $475-76$.

40. 591 F.2d 903 (D.C. Cir. 1978), cert. denied, 440 U.S. 966 (1979).

41. Id. at $921-22$ (citation omitted).

42. Id. at 922 ("After raising the defense of entrapment, the defendant cannot claim lie is prejudiced by evidence indicating that at the relevant time he had a propensity to commit crimes such as those he is accused of committing."). The Supreme Court adopted this same position in Sorrells v. United States, 287 U.S. 435 (1932), noting that "if the defendant seeks acquittal by reason of entrapment he cannot complain of an appropriate and searching inquiry into his own conduct and predisposition as bearing upon that issue." Id. at 451. 
truly predisposed from those who were entrapped. The most important limitation requires that the prior crime must be "similar im kind and reasonably close in time to the crime charged." ${ }^{43}$ Like Rule 404(b), the similarity restriction allows into evidence proof of prior criminal acts that indicates that the defendant possessed the requisite predisposition but excludes the introduction of evidence of prior crimes to show that the defendant acted in conformity with his general criminal character. For example, when the charged offense is possession of marijuana, a prior conviction for possession of heroin is considered similar and therefore admissible; ${ }^{44}$ when the charged offense is the illegal possession of firearms, however, evidence that the defendant committed several burglaries and actively bought and sold stolen goods is deemed not similar and therefore not admissible. ${ }^{45}$

The question of how close in time the prior act must have been to the charged offense is decided on a case-by-case basis: ${ }^{46}$ "[T] here is no absolute rule regarding the number of years that can separate offenses. Rather, the court applies a reasonableness standard and examines the facts and circumstances of each case." ${ }^{\text {47 }}$ It is clear that similar offenses that occurred within the preceding year are admissible. ${ }^{48}$ In Sherman, altliough the Court held that two prior convictions, one five years old and one nine years old, were insufficient to prove a criminal predisposition, it did not hold that the convictions were too remote in time to be

43. United States v. Crump, 934 F.2d 947, 954 (8th Cir. 1991).

44. See United States v. Tyson, 470 F.2d 381, 382-84 (D.C. Cir. 1972), cert. denied, 410 U.S. 985 (1973).

45. United States v. Blankenship, 775 F.2d 735, 740 (6th Cir. 1985).

46. The restriction concerning closeness in time is inposed on other evidentiary uses of prior criminal acts, such as proof of intent, knowledge, notive, and lack of accident, that are express exceptions to the general prohibition on the use of such evidence. See FED. R. EVID. 404(b). As the use of evidence of prior criminal acts to prove predisposition is treated as an imphed exception to Rule 404(b), Burkley, 591 F.2d at 921, the analysis for admissibility is analogous to that of the express exceptions. The following discussion contains citatious to cases that deal with express exceptions as well as entrapnent cases.

47. United States v. Engleman, 648 F.2d 473, 479 (8th Cir. 1981).

48. See, e.g., United States v. Paul, 810 F.2d 774, 777 (8th Cir. 1987) ("The fact that the prior transactions occurred no more than six months prior to the charged crines is sufficiently close in time to eliminate any possible abuse of discretion by the court in admitting the bad acts evidence."); Tyson, 470 F.2d at 384 ("In the present case we are not even confronted with this problem of 'staleness,' simce the challenged conviction occurred only 11 months prior to the date of the offense charged."). 
admissible. ${ }^{49}$ It is not surprising, therefore, that a majority of federal courts find prior criminal acts committed within the last nine years to be "reasonably close in time." that criminal acts committed ten or more years in the past are admissible, ${ }^{51}$ but cases involving such prior acts are not plentiful.

In interpreting the Federal Rules of Evidence, courts have placed another restriction on the government's use of prior acts to rebut an entrapment defense: before evidence of prior acts may be introduced, the prosecution must introduce sufficient evidence for the jury to determine that the defendant actually committed the prior act. ${ }^{52}$ When the defendant has been convicted of the prior act, the standard is met by simply introducing evidence of the conviction. This restriction is therefore most relevant when the prosecution attempts to introduce evidence of prior criminal acts for which the defendant was never convicted.

Prior to 1988, the federal circuit courts of appeals were divided on the question of what burden of proof the prosecution had to meet before evidence of prior criminal acts could be admitted when the defendant had not been convicted of committing the criminal act. The First, Fourth, Fifth, and Eleventh Circuits required the prosecution to present evidence sufficient for the jury to determine that the defendant had committed the prior criminal act $;^{53}$ the Second and Sixth Circuits required proof by a prepon-

49. See Sherman v. United States, 356 U.S. 369, 375-76 (1958).

50. See, e.g., United States v. Franklin, 704 F.2d 1183, 1189 (10th Cir.) (four-year-old conviction relevant), cert. denied, 464 U.S. 845 (1983); United States v. Marshall, 683 F.2d $1212,1214-16$ (8th Cir. 1982) (three- and five-year-old convictions relevant); United States v. Dudley, 562 F.2d 965, 966 (5th Cir. 1977) (six-year-old conviction relevant); United States v. Zeidman, 540 F.2d 314, 319 (7th Cir. 1976) (five-year-old conviction relevant). But see United States v. Burkhart, 458 F.2d 201, 208 (10th Cir. 1972) (four-year-old conviction not relevant).

51. See, e.g., United States v. Walther, 867 F.2d 1334, 1342 (11th Cir.) (ten-year-old conviction relevant), cert. denied, 493 U.S. 848 (1989); United States v. Engleman, 648 F.2d at 479 (thirteen-year-old conviction relevant). But see United States v. Gilliland, 586 F.2d 1384, 1389-90 (10th Cir. 1978) (convictions between fourteen and thirty-four years old not relevant). The practice of allowing into evidence proof of prior criminal acts to prove a predisposition when the prior acts occurred more than ten years previously is at odds with Rule 609(b), which expressly prohibits the introduction of proof of prior convictions to impeach a witness's credibility when the conviction is more than ten years old unless the probative value of such evidence substantially outweighs the potential prejudice. See FED. R. EVID. 609(b).

52. United States v. York, 933 F.2d 1343, 1351-52 (7th Cir.), cert. denied, 112 S. Ct. 321 (1991).

53. See, e.g., United States v. Ingraham, 832 F.2d 229, 235 (1st Cir. 1987), cert. de- 
derance of the evidence; ${ }^{54}$ the Seventh, Eighth, Ninth, and District of Columbia Circuits required the prosecution to present clear and convincing evidence that the defendant committed the prior criminal act. ${ }^{55}$ The Supreme Court settled the burden of proof question in Huddleston v. United States, ${ }^{56}$ holding in a unanimous decision that "[similar act] evidence should be adnitted if there is sufficient evidence to support a finding by the jury that the defendant committed the similar act."

The Huddleston decision is based on Rule 104(b). ${ }^{58}$ If the prosecution presents evidence sufficient to convince a reasonable jury by a preponderance of the evidence that the defendant committed the prior criminal act, evidence of the prior crimimal act will be admitted. ${ }^{59}$ This standard allows the jury to determine for itself whether the defendant engaged in similar conduct at some other time. Under a higher standard, a repeat criminal who had been fortunate enough to avoid a conviction or an indictnient on previous crimes would be released on a successful entrapment defense because the prosecution would be prevented from proving the defendant's predisposition by the introduction of similar act evidence.

nied, 486 U.S. 1009 (1988); United States v. Martin, 773 F.2d 579, 582 (4th Cir. 1985); United States v. Dothard, 666 F.2d 498, 502 (11th Cir. 1982); United States v. Beechum, 582 F.2d 898, 913-14 (5th Cir. 1978) (en banc), cert. denied, 440 U.S. 920 (1979). Evidence is sufficient for such a determination when it ineets the Rule 104(b) test for conditional relevance. Ingraham, 832 F.2d at 235 . For a more complete discussion of this issue, see infra notes 56-57, 159-71 and accompanying text.

54. See, e.g., United States v. Ebens, 800 F.2d 1422, 1432 (6th Cir. 1986) (en banc); United States v. Leonard, 524 F.2d 1076, 1090-91 (2d Cir. 1975), cert. denied, 425 U.S. 958 (1976).

55. See, e.g., United States v. Leight, 818 F.2d 1297, 1302 (7th Cir.), cert. denied, 484 U.S. 958 (1987); United States v. Weber, 818 F.2d 14, 14-15 (8th Cir. 1987); United States v. Vaccaro, 816 F.2d 443, 452 (9th Cir.), cert. denied, 484 U.S. 928 (1987); United States v. Lavelle, 751 F.2d 1266, 1276 (D.C. Cir.), cert. denied, 474 U.S. 817 (1985).

56. 485 U.S. 681 (1988).

57. Id. at 685 .

58. The rule states that "[w]hen the relevancy of evidence depends upon the fulfillment of a condition of fact, the court shall admit it upon, or subject to, the introduction of evidence sufficient to support a finding of the fulfillment of the condition." FED. R. EVID. 104(b).

59. Huddleston, 485 U.S. at 690; see also EDWARD J. IMWINKELRIED, UNCHARGED MISCONDUCT EVIDENCE § 2:06 (1992) (supporting the proposition that the jury should decide whether the defendant committed a prior act of uncharged misconduct as a question of conditional relevance). 
The Huddleston Court acknowledged that this standard might allow in prejudicial evidence but pointed out that the Federal Rules of Evidence contain numerous safeguards that prevent the introduction of prejudicial evidence. ${ }^{60}$ An analysis of cases decided after Huddleston indicates that this standard favors the introduction of prior criminal acts, even when the evidence is not overwhelming. For example, in United States v. Crump, ${ }^{61}$ the uncontroverted testimony of one witness was sufficient to meet the burden of proof. $^{62}$ In United States $v$. York, ${ }^{63}$ the court found the testimony of one witness that the defendant confessed to the prior crime sufficient, although that witness's credibility was strongly impeached. ${ }^{64}$

Finally, prior criminal acts may be excluded under Rule 403 if the potential prejudice to the defendant substantially outweighs the probative value of the evidence. ${ }^{65}$ The rule states that "[a]lthough relevant, evidence may be excluded if its probative value is substantially outweighed by the danger of unfair prejudice." entrapment context, evidence of prior acts will almost always pass the probativity test of Rule 403 . Caselaw suggests that evidence of prior similar criminal acts is highly probative of a criminal predisposition and that the possible prejudicial inferences the jury may draw from this evidence will not substantially outweigh its probative value. ${ }^{67}$ For example, it has been held that the probative val-

\section{The Court stated,}

We share [the defendant]'s concern that unduly prejudicial evidence might be introduced under Rule 404(b). We think, however, that the protection against such unfair prejudice emanates not from a requireinent of a preliminary finding by the trial court, but rather from four other sources: first, from the requirement of Rule 404(b) that the evidence be offered for a proper purpose; second, from the relevancy requirement of Rule 402-as enforced through Rule 104(b); third, from the assessment the trial court must make uuder Rule 403 to determine whether the probative value of the similar acts evidence is substantially outweighed by its potential for unfair prejudice; and fourth, from Federal Rule of Evidence 105, which provides that the trial court shall, upon request, instruct the jury that similar acts evidence is to be considered only for the proper purpose for which it was admitted.

Huddleston, 485 U.S. at 691-92 (citations omitted).

61. 934 F.2d 947 (8th Cir. 1991).

62. Id. at 955 .

63. 933 F.2d 1343 (7th Cir.), cert. denied, 112 S. Ct. 321 (1991).

64. Id. at 1352.

65. United States v. Anderson, 879 F.2d 369, 378 (8th Cir.), cert. denied, 493 U.S. 982 (1989).

66. FED. R, EVID. 403.

67. See, e.g., Sorrells v. United States, 287 U.S. 435, 451-52 (1932) (stating that a defendant cannot object to the possible prejudice that a "searching inquiry" into his past 
ue of evidence showing that the defendant murdered his wife to collect on an imsurance policy was not outweighed by the potential prejudice when the prior murder indicates the defendant's predisposition to defraud an insurance company. ${ }^{68}$ Similarly, the probative value of testimony to the effect that the defendant provided the witness with drugs whenever they engaged in sexual intercourse was not substantially outweighed by the potential prejudice to the defendant when the testimony is used to prove the defendant was predisposed to distribute illegal drugs. ${ }^{69}$

2. Prior Noncriminal Acts. The prosecution also is allowed to introduce evidence of the defendant's prior similar noncriminal acts to prove that the defendant was predisposed to commit the charged offense. Because the defendant who pleads entrapment is denying a criminal predisposition, such evidence is appropriately used to rebut the defendant's claim. The introduction of this evidence must be held to the same standards as is evidence of prior criminal acts because it is being used for exactly the same purposes and is therefore susceptible to the same abuses.

Some courts are more receptive to this type of information than others. In United States $v$. Williams, ${ }^{70}$ one of the $\mathrm{ABSCAM}^{71}$ cases, the prosecutor introduced evidence that Wilhams had used his influence as a U.S. Senator to benefit himself and his wife financially. Although these acts were not technically criminal, the evidence was introduced to show that Williams was predisposed to use his office to influence the contract process in

causes if he asserts an entrapment defense); United States v. Burkley, 591 F.2d 903, 922 (D.C. Cir. 1978) (noting that "[a defendant] is simply not in a position to be prejudiced should the jury infer from his commission of other crimes that he committed the crime charged" if he admits that he engaged in the illegal conduct). For a more complete discussion of this issue, see infra notes 149-57 and accompanying text.

68. York, 933 F.2d at $1350-51$.

69. United States v. Crump, 934 F.2d 947, 955 (8th Cir. 1991).

70. 705 F.2d 603 (2d Cir.), cert. denied, 464 U.S. 1007 (1983).

71. ABSCAM was a government operation designed to identify members of Congress who would accept bribes. Undercover Federal Bureau of Investigation agents posed as representatives of Abdul Enterprises, a fictitious entity, and various Middle Eastern businessmen who wanted to immigrate to the United States. Several members of Congress agreed to use their official positions to assist the agents with immigration and investment matters in exchange for significant cash payments. These congressmen were subsequently arrested and charged with a variety of bribery-related offenses. For an explanation of the undercover operation and resulting charges, see United States $v$ Meyers, 635 F.2d 932, 934-35 (2d Cir.), cert. denied, 449 U.S. 956 (1980). 
favor of someone who had paid him. Despite Williams's contention that the evidence was unfairly prejudicial, the U.S. Court of Appeals for the Second Circuit held that "[c]onduct 'morally indistimguishable' from the offenses charged is probative on the issue of predisposition." 72 The court noted that such evidence was appropriately introduced to show that the defendant did not commit the charged offense solely because of the government's inducement. ${ }^{73}$

The U.S. Supreme Court, however, has taken a more cautious view. In Jacobson v. United States, ${ }^{74}$ the Court in a 5-4 decision held that "evidence that merely indicates a generic inclination to act withm a broad range, not all of which is criminal, is of little probative value in establishing predisposition." ${ }^{75}$ In Jacobson, the defendant was charged with obtaining child pornography through the mail. The prosecution introduced evidence that Jacobson had ordered such material through the mail at a time when there was no federal or state law prohibiting such conduct. The majority's rationale for holding that similar noncriminal conduct is of little probative value appears to be that some people will obey the law even when they have an mclination to violate it: "Evidence of predisposition. to do what once was lawful is not, by itself, sufficient to show predisposition to do what is now illegal, for there is a common understanding that most people obey the law even when they disapprove of it."76

The Supreme Court's decision in Jacobson makes clear that the prosecution cannot prove a criminal predisposition merely by introducing evidence of the defendant's prior similar noncriminal acts. It is significant to note, however, that the Court did not hold

72. Williams, 705 F.2d at 623 (citations omitted).

73. Id.

74. 112 S. Ct. 1535 (1992).

75. Id. at 1541 .

76. Id. at 1542 . As the dissent noted, however, specific intent to violate the law is not an element of the crime with which Jacobson was charged.

The Court seems to add something new to the burden of proving predisposition. Not only must the Government show that a defendant was predisposed to engage in the illegal conduct, here, receiving photographs of minors engaged in sex, but also that the defendant was predisposed to break the law knowingly in order to do so. The statute violated here, however, does not require proof of specific intent to break the law; it requires only knowing receipt of visual depictions produced by using minors engaged in sexually explicit conduct. Under the Court's analysis, however, the Government must prove more to show predisposition than it need prove in order to convict.

Id. at 1546 (O'Connor, J., dissenting) (citation omitted). 
that evidence of this nature was inadmissible, nor did it hold that the prejudice to the defendant caused by the introduction of such evidence substantially outweighed its admittedly low probative value. Indeed, such a holding would undermine the subjective focus of the entrapment defense by preventing the jury from considering evidence indicative of the defendant's predisposition. Thus, although evidence of similar noncriminal conduct cannot prove a criminal predisposition per se, it can be introduced and considered along with other evidence as bearing on the predisposition inquiry.

3. Subsequent Acts. In addition to evidence of prior similar acts, the prosecution also may prove predisposition by imtroducing evidence that the defendant committed acts similar to the charged offense subsequent to the date of the charged offense. ${ }^{77}$ Evidence of subsequent acts is properly adimitted in cases involving the entrapinent defense because the defendant's continuation of the prohibited conduct after the removal of the government inducement indicates that it was not the government's inducement that motivated the defendant to commit the charged offense, but soine other, continuing factor. ${ }^{78}$ Such evidence is therefore probative of the defendant's criminal predisposition.

Several early courts were reluctant to allow the use of this type of evidence. The strongest condemnation of the practice occurred in United States v. Daniels. ${ }^{79}$ In Daniels, the prosecution introduced evidence that the defendant had been charged with possessing a sawed-off shotgun some three months after his alleged sale of heroin to undercover officers. The court held that this

77. See, e.g., United States v. Posner, 865 F.2d 654, 658 (5th Cir. 1989) ("[W]e [have held] that evidence of the defendant's subsequent, extrinsic offense [is] admissible because it fairly rebut[s] the defendant's claim of entrapment by proving disposition to commit a criminal act ....") (citing United States v. Mack, 643 F.2d 1119, 1121-23 (5th Cir. 1981)); United States v. Silvestri, 719 F.2d 577, 583 (2d Cir. 1983) ("The evidence was properly admitted ... to [prove the defendant]'s predisposition, even though this episode occurred after some of the activity with which [the defendant] was charged . ..."); United States v. Moschiano, 695 F.2d 236, 244 (7th Cir. 1982) ("[T] he commission of similar crimes after the indicted offense does have a tendency to make it more probable that the defendant was predisposed to commit the offense charged."), cert. denied, 464 U.S. 831 (1983).

78. United States v. Carreon, 626 F.2d 528, 535 n.14 (7th Cir. 1980) ("While it is true that predisposition turns on a defendant's mental state prior to commission of the crime, that mental state may be proved by relevant and admissible evidence concerning the defendant's actions either before or after commission of the crime.").

79. 572 F.2d 535 (5th Cir. 1978). 
subsequent act was inadmissible because "its probative value is substantially outweighed by the danger of unfair prejudice to the defendant. ${ }^{.80}$ Opposition to the admission of subsequent similar conduct evidence also was shown in United States $v$. Boyd ${ }^{81}$ in which the government sought to admit evidence that the defendants were willing to buy an illegal drug six inonths after their arrests for inanufacturing and distributing different drugs. The court stated that "even recognizing that time and space are only relative concepts, we have not yet come to the point where the government, in meetimg an anticipated entrapment contention, can show predisposition by subsequent activity." 82

Later cases interpreted Daniels to stand for the proposition that evidence of subsequent similar conduct was admissible but less probative than evidence of prior similar conduct. ${ }^{83}$ The courts now agree that evidence of subsequent acts is admissible to prove predisposition, subject to the same restrictions placed on evidence of prior acts. ${ }^{84}$

\section{B. Defendant's Response to Inducement}

Prosecutors can also properly introduce evidence of the defendant's response to the government induceinent because a

80. Id. at 538 (citing FED. R. EvID. 403). The court also noted that the subsequent charge was dissimilar to the charged offense and was inadmissible for that reason as well. Id.

81. 595 F.2d 120 (3d Cir. 1978). In Boyd, the prosecution anticipated that the defendant would allege entrapment and sought to introduce evidence of the defendant's predisposition im its case-in-chief. As it turned out, the defense did not assert an entrapment defense; the defendant's predisposition was therefore never properly an issue before the jury.

82. Id. at 126 (dictum).

83. United States v. Moschiano, 695 F.2d 236, 244 n.13 (7th Cir. 1982) (noting that in cases both prior and subsequent to Daniels, the U.S. Court of Appeals for the Fifth Circuit allowed the prosecution to prove a predisposition by subsequent acts), cert. denied, 464 U.S. 831 (1983). The Moschiano court set out in detail the basis of the defendant's argument that there should be a per se rnle forbidding the admission of subsequent evidence of similar conduct. The court then examined each case the defendant cited and found that none of them supported the proposed per se rule. Id. at 243-44 \& n.13; see also United States v. Jimenez, 613 F.2d 1373, 1376 (5th Cir. 1980) (stating that "[a]lthough we do not suggest that subsequent extrinsic offense evidence could never be admitted under rule 404(b), it certainly bears substantially less on predisposition than would a prior extrinsic offense.") (citing Daniels, 572 F.2d at 538-59).

84. See, e.g., United States v. Mack, 643 F.2d 1119, 1121-23 (5th Cir. 1981); United States v. Burkley, 591 F.2d 903, 921-22 (D.C. Cir. 1978), cert. denied, 440 U.S. 966 (1979). 
defendant's lack of reluctance can show that the defendant was predisposed to commit the crime. The defendant's lack of reluctance is often sufficient, by itself, to prove his predisposition. ${ }^{85}$ The importance of this evidence is not surprising given that the Supreme Court has historically focused on a defendant's reluctance to commit the crime when evaluating entrapment cases. ${ }^{86}$ Looking at a defendant's response to the government's contact is also a inatter of practicality because there is seldom any other evidence of the defendant's state of mind at the relevant time. ${ }^{87} \mathrm{~A}$ defendant's reaction to the government's inducement can be characterized as belonging to one of three classes of possible responses: (1) no reluctance to engage in the crime; (2) reluctance to commit the crime that is overcome only by the government's repeated solicitations; and (3) some initial reluctance followed by actions evincing a willingness to commit the crime.

The no reluctance response clearly imdicates that the defendant was predisposed to commit the crime and that "the Government merely afford[ed] opportunities or facilities for the commission of the offense." ${ }^{.88}$ A lack of reluctance is often accompanied by actions that indicate an eagerness to engage in the illegal activi-

85. "We have found no case in which the defense of entrapment ... was successful where the defendant had not indicated reluctance to engage in illegal activity." United States v. Reynoso-Ulloa, 548 F.2d 1329, 1336 n.11 (9th Cir. 1977), cert. denied, 436 U.S. 926 (1978).

86. Jacobson v. United States, 112 S. Ct. 1535, 1541, 1543 (1992) (finding entrapment as a nuatter of law when the defendant ordered child pornography only after 26 noonths of government inducement); Sherman v. United States, 356 U.S. 369, 373-75 (1958) (holding defendant was entrapped when government informer repeatedly requested defendant to procure drugs for hin, notwithstanding defendant's continued reluctance); Sorrells v. United States, 287 U.S. 435, 440-42 (1932) (reversing conviction and remanding for retrial when undercover agent, "by repeated and persistent solicitation," finally convinced defendant to commit the crime).

87. As one court noted,

In many cases, ... there is hittle direct evidence of the defendant's state of mind prior to interaction with Government agents and we unust instead rely upon indirect proof available through examination of the defendant's conduct after contact with the agents. Should the defendant initially reject a suggestion that he commit a crime this is indicative of a lack of predisposition. Conversely, should he initiate contact with the agents in order to commit a crime this is strong proof of predisposition.

United States v. Kaminski, 703 F.2d 1004, 1008 (7th Cir. 1983).

88. Sorrells, 287 U.S. at 441; see also United States v. Fleishnian, 684 F.2d 1329, 1343 (9th Cir.) ("There was no evidence to contradict the fact that [the defendant] was ready, willing, and able to engage in narcotic transactions and the agents merely provided him a propitious opportunity to do so."), cert. denied, 459 U.S. 1044 (1982). 
ty, and such actions are additional proof that the defendant did not engage in the criminal conduct solely as a result of the government inducement. ${ }^{89}$ The defendant in United States v. Busby ${ }^{90}$ exhibited both a lack of reluctance and actions indicating a ready willingness to commit the crime. ${ }^{91}$ In Busby, the defendant acted as a middleman, connecting potential drug buyers and sellers. At their first meeting, the defendant agreed to introduce the government informer to someone willing to sell cocaine. The defendant arranged the introduction, and the informer agreed to buy the cocaine as soon as he could find "financial backers." Shortly after the introduction, the defendant called the informer to make sure the deal would proceed and personally bought samples for the informer to give to his backers. ${ }^{92}$ The court held that these facts were sufficient to show that the defendant was predisposed and that the district court did not err in its refusal to instruct the jury on the defense of entrapment..$^{93}$

Conversely, the defendant may introduce evidence of his reluctance to engage in the crime with which he is charged to show that he was entrapped. The Supreme Court first adopted this view in Sorrells v. United States ${ }^{94}$ and strengthened its position in Sherman $v$. United States. ${ }^{95}$ The most egregious case of repeated government solicitation overcoming a defendant's reluctance to engage in illegal activity occurred in Jacobson v. United States. ${ }^{96}$ In Jacobson, the government bounbarded a Nebraska farmer, who had no prior convictions, with advertisements and communications

89. See United States v. Arteaga, 807 F.2d 424, 425-26 (5th Cir. 1986) (finding that defendant offered informant cocaine on his own initiative, eagerly dealt with government agents, and asked agents to call him if they wanted to buy more cocaine); United States v. Andrews, 765 F.2d 1491, 1499-500 (11th $\mathrm{Cir}$.) (finding that defendant readily agreed to inducement, set the terms of the illegal transactions, and met with agent before prearranged meeting time to continue discussing the transaction), cert. denied, 474 U.S. 1064 (1985); United States v. Navarro, 737 F.2d 625, 628 (7th Cir.) (finding that defendant offered to arrange delivery of drugs at first ineeting and contacted agents "numerous times during the following week"), cert. denied, 469 U.S. 1020 (1984).

90. 780 F.2d 804 (9th Cir. 1986).

91. Id. at 806 .

92. Id. at $805-06$.

93. Id. at 808 .

94. See 287 U.S. 435, 451 (1932).

95. See 356 U.S. 369, 373 (1958) (holding that the defendant was entrapped as a matter of law on the basis of informant's testimony that "[o]ne request was not enough, ... a additional ones were necessary to overcome, first, [defendant]'s refusal, then his evasiveness, and then his hesitancy in order to achieve capitulation").

96. 112 S. Ct. 1535 (1992). 
urging him to order child pornography by mail. The government's campaign consisted of no fewer than ten mailings to the defendant over a period of twenty-seven months. ${ }^{97}$ The U.S. Court of Appeals for the Eighth Circuit affirmed the conviction, but a majority of the Supreme Court reversed, holding that the defendant had been entrapped as a matter of law. ${ }^{98}$ Although the level of government involvement in Jacobson was extreme, other cases make it clear that this level of government pressure is not necessary to prove that the defendant lacked the requisite predisposition. ${ }^{99}$

The third class of possible responses to government inducement-an initial reluctance followed by actions evincing a willingness to commit the crime-is the most problematic for courts because it has elements of the other two classes of responses. Despite defense argnınents that an initial reluctance shows a lack of predisposition and that this alone proves entrapment, the courts wisely examine the defendant's conduct throughout the episode to evaluate the claim of entrapinent. They do so because otherwise "[criminals] could immunize thenselves fronı prosecution by the artifice of always vigorously refusing the mitial offer." 100 The cases indicate that if the defendant shows some initial reluctance but then voluntarily takes an active role in the commission of the crime, he possesses the necessary predisposition and therefore was not entrapped. ${ }^{101}$

The leading case in this area is United States v. PerezLeon. ${ }^{102}$ In Perez-Leon, the defendant was approached by an in-

97. United States v. Jacobson, 916 F.2d 467, 471 (8th Cir. 1990) (Heaney, J., dissenting), rev'd, 112 S. Ct. 1535 (1992).

98. "[ $] \mathrm{t}$ is our view that the Government did not prove that this predisposition was independent and not the product of the attention that the Government had directed at [the defendant]." Jacobson, $112 \mathrm{~S}$. Ct. at 1541.

99. See, e.g., United States v. Knight, 604 F. Supp. 984, 987 (S.D. Ohio 1985) (finding defendant not guilty under successful entrapment defense when "repeated Government importuning overcame his reluctance" to commit the crime).

100. United States v. Kelly, 748 F.2d 691, 699 (D.C. Cir. 1984). The court also held that "it is simply not the law that predisposition is to be determined based solely on the defendant's reaction to his first encounter with the corrupt offer." Id.

101. See, e.g., id. at 699-701 (finding that defendant in bribery case was predisposed when initial reluctance was only directed at physically taking the money and defendant actively participated in later meetings); United States v. Thoma, 726 F.2d 1191, 1197-98 (7th Cir.) (finding that defendant was not entrapped into dealing in child pornography when initial reluctance was due to fear of arrest and defendant exhibited no further reluctance after consummating the first transaction), cert. denied, 467 U.S. 1228 (1984).

102. 757 F.2d 866 (7th Cir.), cert. denied, 474 U.S. 831 (1985). 
formant and, after indicating that he did not want to deal in drugs because he had "been burned before," offered to take the informant's name and to contact him if he found soineone interested in dealing drugs. ${ }^{103}$ In later ineetings, the defendant actively negotiated with the informant, suggested that the informant speed up the process, and inquired into the possibility of future transactions. The court affirmed the defendant's convictions and noted that " $\mathrm{t}] \mathrm{he}$ evidence ... establishes that [the informant] solicited the deal and that [the defendant] expressed slight hesitation, which may have been caused by the very nature of drug transactions in that a new buyer is usually checked and cross-checked to the best of his supphier's abihity." 104 Thus, the defendant's initial reluctance can be outweighed by subsequent, voluntary actions indicating a desire to commit the crime. This reasoming is especially convincing when the defendant's initial reluctance can be explained as a precaution to avoid sting operations.

\section{Defendant's Reputation}

The prosecution also may introduce evidence of a defendant's reputation to prove his predisposition to commit the charged offense. ${ }^{105}$ Such a rule promotes the goal of the entrapinent defense because it is highly unlikely that a defendant with no predisposition would have the reputation of being involved in criminal activity. It is clear froin the cases, however, that a reputation witness inust have a personal basis of knowledge before he can testify about the defendant's reputation. ${ }^{106}$ The witness's testimony that he hives or works in the community and that he is fainiliar with the defendant's reputation is sufficient to show such knowledge. ${ }^{107}$ Once the witness's knowledge of the defendant's reputation is established, he is free to testify that the defendant had a

103. Id. at 869 .

104. Id. at 872 .

105. See, e.g., United States v. Casanova, 970 F.2d 371, 375 (7th Cir. 1992); United States v. Barger, 931 F.2d 359, 366 (6th Cir. 1991); United States v. Smith, 924 F.2d 889, 898 (9th Cir. 1991); United States v. Alston, 895 F.2d 1362, 1368 (11th Cir. 1990).

106. See, e.g., Whiting v. United States, 296 F.2d 512, 517 (1st Cir. 1961). This common law rule is in accord with Rule 602, which states, "A witness may not testify to a matter unless evidence is introduced sufficient to support a finding that the witness has personal knowledge of the nutter." FED. R. EVID. 602.

107. Whiting, 296 F.2d at 517. 
reputation of being involved in that type of illegal activity with which the defendant is now charged. ${ }^{108}$

It is only possible to get such testimony, however, if the witness, often an informant, is willing to be identified and to testify at trial. If the witness is unwilling to testify, the prosecution will often atteinpt to have a government agent involved in the operation relate to the jury what the witness told him about the defendant's reputation. Such testimony is double hearsay and outside the exception allowing the adimission of reputation testimony. Most federal circuit courts of appeals have refused to allow hearsay testimony of reputation to be introduced. ${ }^{109}$ The U.S. Court of Appeals for the Fifth Circuit initially allowed government agents to present such hearsay evidence of the defendant's reputation, ${ }^{110}$ but the practice was highly criticized.

It is one thing to conduct an inquiry into the [defendant]'s past conduct and elicit the fruits of this search by competent evidence to show evil prochivities. It is quite another to attempt to accoinplish this same objective by lofting into the jury box the basis of officials' suspicion, however evidentiary ephemeral [sic] these latter inay be. ${ }^{111}$

In United States $v$. Webster, ${ }^{112}$ the Fifth Circuit overruled its prior decisions and held that hearsay evidence of reputation was

108. FED. R. EVID. 803(21) expressly declares that testimony concerning a person's reputation among inembers of the community is an exception to the rule against hearsay.

109. See, e.g., United States v. Hunt, 749 F.2d 1078, 1082 (4th Cir. 1984), cert. denied, 472 U.S. 1018 (1985); United States v. McClain, 531 F.2d 431, 435-37 (9th Cir.), cert. denied, 429 U.S. 835 (1976); Umited States v. Ambrose, 483 F.2d 742, 752 (6th Cir. 1973); United States v. Johnston, 426 F.2d 112, 113-14 (7th Cir. 1970); United States v. Catanzaro, 407 F.2d 998, 1001 (3d Cir. 1969); Whiting, 296 F.2d at 517-18.

110. See, e.g., United States v. McKinley, 493 F.2d 547, 552 (5th Cir. 1974) (holding that hearsay reputation evidence is admissible when defendant asserts an entrapment defense); United States v. Simon, 488 F.2d 133, 134 (5th Cir. 1973) (sanie); United States v. Stills, 476 F.2d 592, 593 (5th Cir. 1973) (same). The U.S. Court of Appeals for the Tenth Circuit also allowed the use of hearsay testiniony of the defendant's reputation to prove the defendant's predisposition, but that case is distinguishable because the defendant agreed to the admission of such evidence. See United States v. Gurule, 522 F.2d 20, 24 n.7 (10th Cir. 1975) ("Hearsay, by defendant's own admission, is admissible to show 'predisposition.' "), cert. denied, 425 U.S. 976 (1976).

111. Ambrose, 483 F.2d at 750-51 (holding hearsay testiniony of reputation evidence by government agents madmissible to prove predisposition in attempting to defeat defendant's claim of entrapment) (quoting Whiting, 296 F.2d at 517-19). Commentators also strongly condemned the practice of allowing hearsay testimony to be used to prove a predisposition. See, e.g., Park, supra note 2, at 248-49.

112. 649 F.2d 346 (5th Cir. 1981) (en banc). 
inadmissible to prove a criminal predisposition when the defendant alleged entrapment. The court examined prior cases and classified the use of hearsay evidence of reputation into three categories: (1) statements made by an informant to a government agent about the defendant's reputation; (2) statements made by an informant to a government agent about specific criminal activities of the defendant; and (3) statements from various sources that had been recorded in pohice reports. ${ }^{113}$ The court held that because all three types of statements were hearsay to which there was no valid exception, none was admissible to prove the defendant's predisposition. ${ }^{114}$ The federal courts now umiformly hold hearsay evidence of the defendant's reputation madinissible.

Although hearsay evidence of reputation is inadınissible to prove a defendant's predisposition, a statement that is defined as non-hearsay ${ }^{115}$ or that qualifies as an exception to the rule against hearsay ${ }^{116}$ is admissible. ${ }^{117}$ For example, an admission by the defendant is admissible to prove predisposition. ${ }^{118}$ Similarly, a statement by the defendant's co-conspirator concerming the defendant's reputation is admissible. ${ }^{119}$

113. Id. at 349 .

114. Id. at 350 (footnote omitted). The court reached this decision after reviewing the rationale for the rule against hearsay.

Our creation of a rule that allows gross hearsay evidence to be used to prove predisposition has resulted in the very evils that the rule against hearsay was designed to prevent. The jury is free to believe the unsworn, unverified statements of government informants, sometimes unidentified, whose credibility is not subject to effective testing before the jury and whose motivations may be less than honorable. We are hard pressed to envision a situation where the disparity between the probative value and prejudicial effect of evidence is greater. Finding mapplicable the exceptions to the rule against hearsay enumerated in the Federal Rules of Evidence, we hold that hearsay evidence is never admissible Id. for the purpose of proving the defendant's predisposition.

115. See FED. R. EVID. 801(d).

116. See FED. R. EVID. 803, 804.

117. United States v. Hunt, 749 F.2d 1078, 1082 (4th Cir. 1984) ("[H]earsay evidence may not ordinarily be used as proof of predisposition where an entrapment defense is made, unless otherwise admissible under a recognized hearsay exception."), cert. denied, 472 U.S. 1018 (1985).

118. United States v. Nixon, 777 F.2d 958, 964 (5th Cir. 1985) (holding defendant's statements about his prior smuggling activities admissible under Rule $801(\mathrm{~d})(2)(\mathrm{A})$ to prove predisposition).

119. United States v. Miller, 799 F.2d 985, 991 (5th Cir. 1986) (holding coconspirator's statements about defendant's reputation and prior acts admissible under Rule $801(d)(2)(E)$ to prove predisposition). 
Hearsay evidence of reputation is admissible, however, to rebut the defendant's claim of outrageous government conduct. ${ }^{120}$ Once the defendant questions the government's investigative activities by alleging outrageous conduct, the prosecution is free to use hearsay testimony of the defendant's reputation to show the government's good faith and the existence of a reasonable basis for investigating the defendant. ${ }^{121}$ If hearsay testimony of the defendant's reputation is admitted, the defendant is entitled to have a limiting instruction read to the jury cautioning it to use the hearsay evidence only in considering whether the government acted outrageously. ${ }^{122}$

\section{Defendant's Ability to Perform the Illegal Act}

A criminal predisposition also is indicated if the defendant is able to perform an illegal act without significant difficulty, or if the defendant exhibits extensive knowledge concerning the illegal act. It is unlikely that the average citizen who lacks a predisposition to engage in the illegal conduct will have the ability or knowl-

120. See Hunt, 749 F.2d at 1084; United States v. Thoma, 726 F.2d 1191, 1198 n.2 (7th Cir.), cert. denied, 467 U.S. 1228 (1984). The defense of outrageous government conduct is similar to the objective view of entrapment in that it focuses on the actions of the government and its agents rather than the predispodition of the defendant. Unlike the entrapment defense, however, which has its basis in statutory law, Sorrells v. United States, 287 U.S. 435, 445-49 (1932), the outrageous conduct defense is based on the defendant's constitutional right to due process. This defense was first suggested by the Supreme Court in United States v. Russell, 411 U.S. 423 (1973), when the Court stated that "[w]hile we may some day be presented with a situation in whicl the conduct of law enforcement agents is so outrageous that due process principles would absolutely bar the government from invoking judicial processes to obtain a conviction, the instant case is distinctly not of that breed." Id. at 432 (citation omitted). For an in-depth discussion of this defense, see Gail M. Greaney, Note, Crossing the Constitutional Line: Due Process and the Law Enforcement Justification, 67 NOTRE DAME L. REV. 745 (1992).

121. "In rare circumstances governmental good faitl, motive, and reasonableness may take on significance beyond the scope of entrapment vel non . . . . It would then be appropriate to allow the government to prove that the agent acted with proper motive in pursuing the defendant." United States v. Webster, 649 F.2d 346, 351 (5th Cir. 1981) (en banc); see also Hunt, 749 F.2d at 1083-84 (holding learsay concerning defendant's reputation and prior acts admissible to rebut defendant's charge that the government had no basis for mvestigating him).

122. "When evidence whiclt is admissible . . . for one purpose but not admissible . . . for another purpose is admitted, the court, upon request, shall restrict the evidence to its proper scope and instruct the jury accordingly." FED. R. EvID. 105; see also Hunt, 749 F.2d at 1084 n.8 (noting that "the defendant [was] entitled to a limiting imstruction, providing that the testimony of the agents was not to be considered for the truth of the matters asserted, and did not bear in any way on defendant's entrapment claim"). 
edge to commit the offense quickly and easily. ${ }^{123}$

[T] he readiness and celerity with which a defendant comported with the government overtures, his demonstrable orientation to and familiarity with the relevant course of activity and his access to the sources of the pertinent market place would surely be relevant indicia that he was not among the uninitiated in the forbidden traffic. ${ }^{124}$

Using a defendant's ability to perform illegal acts to prove a predisposition is nost common in cases involving the sale of controlled substances. ${ }^{125}$ In United States $v$. Perez-Leon, ${ }^{126}$ the defendant was charged with possession of cocaine with the intent to distribute and with the distribution of cocaine. The prosecution rebutted the defendant's claim of entrapinent by introducing evidence of his ability to obtain two kilograns of cocaine with a street value of $\$ 1.2$ milhon in only two weeks. ${ }^{127}$ Similarly, a defendant's knowledge of the procedures and processes involved in consummating the illegal act is probative evidence of a predisposition to engage in the illegal conduct. ${ }^{128}$ The defendant's knowledge also may be shown by the way in which he engages in the illegal activity. ${ }^{129}$

123. The reason for this difficulty is the secretive nature of illegal enterprises and the care that the operators of such enterprises take when dealing with new and unknown parties. For a more complete discussion of this point, see supra notes 100-104 and accompanying text.

124. Whiting v. Umited States, 296 F.2d 512, 516-17 (1st Cir. 1961).

125. See United States v. Beissel, 901 F.2d 1467, 1469 (8th Cir. 1990) (stating that "[a] defendant's ability to supply large quantities of drugs sloortly after being requested to do so is probative evidence of predisposition"); see also United States v. MendozaSalgado, 964 F.2d 993, 1002 (10th Cir. 1992) ("[Defendant] volunteered that he could supply kilogram quantities of cocame . . . ."); United States v. Arteaga, 807 F.2d 424, 426 (5th Cir. 1986) ("[Defendant] assured [agent] that, with two hours' notice, he could supply any quantity desired."); United States v. Gunter, 741 F.2d 151, 154 (7th Cir. 1984) ("Defendants were able to acquire large quantities of cocaine on short notice ....").

126. 757 F.2d 866, 868 (7th Cir.), cert. denied, 474 U.S. 831 (1985).

127. Id. at 872 n.5.

128. Mendoza-Salgado, 964 F.2d at 1003 ("[Defendant]'s vocabulary and manner of dealing with [the government agent] evidences more than a passing knowledge of the illicit drug trade and strongly implicates him in the illegal activity.").

129. Id. (describing defendant's reluctance to discuss narcotics transaction over the telephone as indicative of his fear that the line might be tapped); Beissel, 901 F.2d at 1469 (implying that defendant wanted to transact drug sale in moving vehicle rather than stationary vehicle to attract less attention). 


\section{E. Defendant's Profit Motive}

Finally, the prosecution can use evidence of the defendant's intent to profit from the illegal transaction to demonstrate a predisposition to commit the charged offense. ${ }^{130}$ The defendant's expectation of profiting from the illegal conduct provides the prosecution with a compelling motive for the crime that effectively rebuts the defendant's claim that his only motivation was the government. In United States $v$. Williams, ${ }^{131}$ a U.S. Senator was convicted of bribery, conspiracy, and conflict of interest violations. Although the defendant claimed he was entrapped, the evidence showed that he stood to receive millions of dollars if he could secure government contracts for a corporation in which he owned a significant interest. ${ }^{132}$

The cases are clear, however, that the profit does not have to be substantial to undermine the defendant's claim of entrapment. ${ }^{133}$ In United States v. Dozal-Bencomo, ${ }^{134}$ the court characterized as a "willing and cooperative middleman" a defendant who received a total of $\$ 200$ in profit from five heroin transactions. ${ }^{135}$ The profit also can be indeterminate ${ }^{136}$ or a percentage of future profits. ${ }^{137}$

130. See Sherman v. United States, 356 U.S. 369,375 (1958). In holding that the defendant had been entrapped as a matter of law, the Suprene Court noted that "[ $t]$ here is no significant evidence that [defendant] even niade a profit on any sale to [the government's informantl." Id. The defendant had charged the informant his cost plus the expenses of acquiring the drugs. Id. at 371.

131. 705 F.2d 603 (2d Cir.), cert. denied, 464 U.S. 1007 (1983).

132. Senator Williams owned approximately $14 \%$ of a mining corporation. He agreed to use his position as a U.S. Senator to assist the corporation in obtaining a lucrative governmeut contract. Once the contract was awarded, a fictitious Arab financier was either to loan the corporation $\$ 100$ million or to buy it for $\$ 70$ million. Id. at 606-07.

133. See, e.g., United States v. Young, 954 F.2d 614, 617-18 (10th Cir. 1992) (defendant sought profit of either $\$ 1000$ or one pound of free marijuana); United States $v$. Hinton, 908 F.2d 355, 358 (8th Cir. 1990) (defendant expected to make $\$ 800$ profit on sale of eight ounces of cocaine); United States v. Navarro, 737 F.2d 625, 628 (7th Cir.) (defendants were to receive a $\$ 3000$ commission for arranging the sale of $\$ 35,000$ of cocaine), cert. denied, 469 U.S. 1020 (1984); United States v. Kaminski, 703 F.2d 1004, 1006 (7th Cir. 1983) (defendant accepted offer of $\$ 1000$ to burn down tavern).

134. 952 F.2d 1246 (10th Cir. 1991).

135. Id. at 1251.

136. See, e.g., United States v. Casanova, 970 F.2d 371, 376 (7th Cir. 1992) (defendant admitted that he "engaged in the illegal activity to make a 'quick buck'").

137. See, e.g., United States v. Reynoso-Ulloa, 548 F.2d 1329, 1332 (9th Cir. 1977) (defendant expected to share in a commission equal to $10 \%$ of the gross profit made on the sale), cert. denied, 436 U.S. 926 (1978). 


\section{DEFENSE OF THE ENTRAPMENT DEFENSE}

Some commentators have vehemently denounced the evidentiary rules discussed in the preceding Part as being unfair to defendants. ${ }^{138}$ By attacking these evidentiary rules, critics are attemptimg to shield defendants from "an appropriate and searching inquiry"139 into their predispositions to commit the charged offenses. In particular, these criticisms charge that the admission of similar act and reputation evidence is unfairly prejudicial to defendants. In addition, they claim that the Huddleston standard of admissibility for similar act evidence is too low and that the defendant's similar subsequent acts are irrelevant to a determination of the defendant's predisposition. Finally, the critics contend that many defendants forgo a viable entrapment defense to avoid the introduction of unfavorable reputation testimony.

An examination of each of these contentions reveals that the critics' allegations are misdirected. The current evidentiary rules accurately and fairly achieve the public policy goal of the entrapment defense-the acquittal of only those defendants who engaged in the prohibited conduct but lacked the necessary criminal mentality.

\section{A. Similar Act Evidence}

Many academic criticisms ${ }^{140}$ of the current evidentiary framework used in proving a defendant's criminal predisposition focus on the use of evidence of the defendant's conduct that is similar to the charged offense. ${ }^{141}$ These criticisms can be categorized into the following contentions: (1) the introduction of similar act evidence is unfairly prejudicial to the defendant; (2) the standard for

138. See, e.g., infra notes $144-49,178-79$ and accompanying text.

139. Sorrells v. United States, 287 U.S. 435,451 (1932).

140. The academic criticisms analyzed and evaluated in this Note are often criticisms of the Federal Rules of Evidence in general, rather than specific criticisms of the rules as they apply to the federal entrapment defense. As a change in the Federal Rules of Evidence would result in a corresponding change in the evidentiary framework of the entrapment defense, it is appropriate to evaluate these criticisms from the perspective of their impact on the entrapment defense.

141. See, e.g., IMWINKELRIED, supra note 59, \$1:04 ("Uncharged misconduct is probably second only to the hearsay doctrine in terms of the volume of academic commentary."); William Roth, Understanding Admissibility of Prior Bad Acts: A Diagrammatic Approach, 9 PEPP. L. REv. 297, 299 (1982) (referring to the "vast amount of literature on the subject"). 
the admissibility of similar act evidence set by the U.S. Supreme Court in Huddleston v. United States ${ }^{142}$ is too lenient; ${ }^{143}$ and (3) the introduction of similar acts subsequent to the alleged crime should be inadmissible because it is not relevant.

Many commentators claim that the introduction of similar act evidence in general and "uncharged misconduct evidence"144 in particular is unfairly prejudicial to the criminal defendant. ${ }^{145}$ According to these commentators, the introduction of such evidence can prejudice the defendant in eitler of two ways. The first form of possible prejudice results when the jury infers that a defendant is more likely to have committed the instant crinie if he has been convicted of committing a prior crime: ${ }^{146}$ "[There] is the tenden-

142. 485 U.S. 681 (1988).

143. For a discussion of Huddleston's impact on federal circuit courts of appeals' holdings, and the manner in which it is currently being interpreted, see supra text accompanying notes $53-64$.

144. "Uncharged misconduct evidence" is the term Professor Imwinkelried uses to describe the defendant's prior or subsequent acts that are sought to be introduced against him at trial but for which the defendant has never been convicted. This term includes criminal as well as noncrimimal acts. IMwINKELRIED, supra note 59, § 1:01. This Note has avoided using the term until this point because it is important to distinguish the different types of uncharged misconduct evidence in analyzing the federal courts' various rationales for allowing the use of each type of evidence. The term is introduced at this point because it has gamed widespread acceptance in the academic community and is frequently used in academic criticisms.

145. See, e.g., IMWINKELRIED, supra note 59, § 1:02 ("Evidence of uncharged misconduct strips the defendant of the presumption of innocence."); HARRY KALVEN, JR. \& HANS ZEISEL, THE AMERICAN JURY 179 (1966) ("The jury's broad rule of thumb here, presumably, is that as a matter of human experience it is especially unikely that a person with no prior record will commit a serious crime ...."); 1 CHARLES T. MCCORMICK, MCCORMICK ON EVIDENCE § 190 (John W. Strong ed., 4th ed. 1992) ("The evidence of bad character would not be irrelevant, but in the setting of the jury trial particularly the dangers of prejudice, confusion and time-consumption outweigh the probative value."); Richard B. Kuhns, The Propensity to Misunderstand the Character of Specific Acts Evidence, 66 IowA L. REV. 777, 803 (1981) ("[T]hat specific acts are inadmissible to prove character to show action in conformity with character rests on the premise 'that extrinsic acts evidence is fraught with dangers of prejudice-extraordinary dangers not presented by other types of evidence" " (quoting Urited States v. Beechum, 582 F.2d 898, 920 (5th Cir. 1978) (Goldberg, J., dissenting), cert. denied, 440 U.S. 920 (1979))).

There is some empirical evidence to support the proposition these writers advance. See, e.g., KALVEN \& ZEISEL, supra, at 177-81 (describing results of a Umiversity of Chicago Law School study that examined the effect on a jury that the introduction - of defendants' prior acts caused); London School of Econonics Jury Project, Juries and the Rules of Evidence, 1973 CRIM. L. REV. 208 (describing results of jury re-enactments of trials using actual transcripts but varying whether evidence of defendants' prior acts was admitted).

146. See Michael H. Graham, Handbook of Federal Evidence $\$ 404.5$ (3d ed. 
cy to infer that because the accused committed one crime, he committed the crime charged. In many instances this inference rests on no greater foundation than the behef that commission of the crime indicates a propensity to commit others." 147 The second form of possible prejudice results when the jury infers that because of his prior crimes, the defendant is a "bad man" and deserves to be punished regardless of whether he committed the instant crime. ${ }^{148}$ It has also been suggested that when evidence of uncharged misconduct is admitted, a jury might convict a "bad man" for the charged offense to prevent him from committing future crimes. ${ }^{149}$

These commentators do not argue that such evidence is not relevant. To the contrary, most commentators admit that "recidivism rates suggest that information that an imdividual has committed one crime is likely to be highly relevant in deciding whether he has committed another crime, particularly if the two crimes are similar in nature." ${ }^{150}$ Excluding similar act evidence thus would

1991); D. Craig Lewis, Proof and Prejudice: A Constitutional Challenge to the Treatment of Prejudicial Evidence in Federal Criminal Cases, 64 WASH. L. REV. 289, 323 (1989) ("[T] he admission of evidence of uncharged misconduct [is prohibited] when offered to support the inference that a person acted in a certain way from a general disposition to do so, because of the belief that the evidence would be dangerously prejudicial when used for this purpose."); Judith M.G. Patterson, Evidence of Prior Bad Acts: Admissibility Under the Federal Rules, 38 BAYLOR L. REv. 331, 333 (1986) ("[U]pon learning that the accused committed other crimes or wrongs, jurors might infer that the defendant has a propensity to commit crimes and probably committed this crime as charged.").

147. See Note, Other Crimes Evidence at Trial: Of Balancing and Other Matters, 70 YALE L.J. 763, 763-64 (1961).

148. As one commentator stated,

[E]vidence of uncharged inisconduct can lead a jury to convict an accused, even if guilt of the charged offense has not been clearly demonstrated, because the accused has been shown either to be a person deserving of punishment for bad character or to be guilty of other sins for which the accused has never been punished.

Lewis, supra note 146, at 325; see also GRAFAM, supra note 146, § 404.5; IMWINKELRIED, supra note 59, § 1:03; RICHARD O. LEMPERT \& STEPHEN A. SALTZBURG, A MODERN APPROACH TO EVIDENCE 218-19 (2d ed. 1982); Note, supra note 147, at 763 ("[There] is the tendency to convict a man of the crime charged, not because he is guilty of that offense, but because evidence introduced indicates that he had committed another unpunished crime or that he is a 'bad man' who should be incarcerated regardless of his present guilt.").

149. Patterson, supra note 146, at 333 ("Although reasonable doubt of guilt exists on this occasion, the jury might conclude the defendant is a 'bad man,' who deserves punishment regardless of his innocence of the crime charged and warrants imprisonment to prevent future maleficent acts.").

150. LEMPERT \& SAITZBURG, supra note 148, at 216; see also Jennifer Y. Schuster, Uncharged Misconduct under Rule 404(b): The Admissibility of Inextricably Intertwined 
keep highly probative and relevant information from the jury. Because the evidence of a defendant's similar acts is relevant, it should only be excluded if its probative value is substantially outweighed by the potential for unfair prejudice to the defendant. ${ }^{151}$ Within the context of the entrapment defense, the prejudice to the defendant that the introduction of similar act evidence causes will almost never outweigh its probativity.

First, $\mathrm{m}$ claiming that he was entrapped, the defendant imphicitly acknowledges that he engaged in the prohibited activity. ${ }^{152}$ If the defendant does deny engaging in the prohibited activity, the involvement of federal agents almost always ensures that rehable witnesses will be available to refute the defendant's demal of engaging in the illegal activity. Because of the defendant's imphicit acknowledginent or the testimony of federal agents, the danger of proving propensity by prior acts does not exist; the very imvocation of the entrapment defense solves the question of whether the defendant committed the crime.

Second, even if similar act evidence does prejudice the defendant, the defendant himself opens the door to this prejudice by claiming that he was entrapped. When a defendant claims that he is not guilty by reason of entrapment, he asserts that he had no disposition to commit the charged offense before government agents induced him. This claim brings before the court the issue of

Evidence, 42 U. MIAMI L. REV. 947, 947-48 (1988) ("The rule excluding uncharged misconduct evidence is not based on lack of relevance, because a defendant's past criminal activity is likely to be probative of his guilt in a particular case."); Kuhns, supra note 145, at 777 (" $[1] \mathrm{f}$ the factfinder knows that an assault defendant has committed numerous assaults in the past, the factfinder could reasonably conclude that it is more likely that the defendant beliaved violently on the occasion in question than it would be if nothing were known about the defendant's past behavior."). The Supreme Court also has acknowledged that prior criminal acts are relevant to determining the guilt of a defendant.

The state may not show defendant's prior trouble with the law, specific criminal acts, or ill name among his neighbors, even though such facts might logically be persuasive that he is by propensity a probable perpetrator of the crime. The inquiry is uot rejected because character is irrelevant; on the contrary, it is said to weigh too much with the jury and to so overpersuade them as to prejudge [the defendant] ....

Michelson v. United States, 335 U.S. 469, 475-76 (1948) (footnote omitted).

151. See FED. R. EVID. 403.

152. Although it is technically possible for a defendant to claim that he was both entrapped and did not engage in the illegal conduct, see Mathews v. United States, 485 U.S. 58 (1988), it is unlikely that a jury would beheve either of these claims. Id. at 67 (Scalia, J., concurring) ("[W]Len genuine imconsistency exists its effect in destroying the defendant's credibility will suffice to protect the interests of justice."). 
predisposition, and the defendant should not be allowed to bring an issue mto question and then foreclose the prosecution from arguing the issue by claiming such an argument would unfairly prejudice him. The Supreine Court, in its first entrapinent case, inade this point clear.

[I]f the defendant seeks acquittal by reason of entrapment he cannot complain of an appropriate and searching inquiry into his own conduct and predisposition as bearing on that issue. If in consequence he suffers a disadvantage, he has brought it upon himself by reason of the nature of the defense. ${ }^{153}$

Third, similar act evidence is introduced to prove that the defendant was predisposed to act in a certain way; the government does not use such evidence to prove that the defendant acted in conformity with his propensity. ${ }^{154}$ Critics frequently ignore this distinction. To einphasize it, the court reads a limiting instruction $^{155}$ to the jury. This limiting instruction emphasizes that similar act evidence can be used only to determime whether the defendant was predisposed and may not be used to determine his guilt or innocence on the instant charge. ${ }^{156}$

Finally, certain other procedural safeguards prohibit the improper use of similar act evidence. These procedures apply not only to cases involving the entrapment defense but to all cases in which similar act evidence is admitted. The requirement that evi-

153. Sorrells v. United States, 287 U.S. 435, 451-52 (1932); see also United States v. Burkley, 591 F.2d 903, 922 (D.C. Cir. 1978) ("After raising the defense of entrapment, the defendant cannot claim he is prejudiced by evidence indicating that at the relevant time he had a propensity to commit crimes such as those he is accused of committing."), cert. denied, 440 U.S. 966 (1979).

154. See Burkley, 591 F.2d at $921-22$.

155. See FED. R. EVID. 105.

156. Some commentators claim that a limiting instruction on the use of similar act evidence is insufficient to guarantee that the jury will not use the evidence in its consideration of the defendant's guilt on the instant charge. See Cynthia L. Randall, Note, Acquittals in Jeopardy: Criminal Collateral Estoppel and the Use of Acquitted Act Evidence, 141 U. PA. L. REV. 283, 313 (1992) ("Whatever the effectiveness of such [limiting] instructions in other contexts, ... it is difficult, if not impossible, for juries to ignore the prejudicial implications of other act evidence."); Note, supra note 147, at 777 ("[T] hese [limiting] instructions are frequently if not always fruitless."). The U.S. Supreme Court has considered and rejected this claim. In Dowling v. United States, 493 U.S. 342 (1990), the Court ruled that the Due Process Clause is not violated by giving a limiting instruction to the jury concerning the proper use of similar act evidence introduced under Rule 404(b): "[I]n light of the limiting instructions provided by the trial judge, we cannot loold that the introduction of [similar act evidence] inerits . . . condemnation." Id, at 353. 
dence of the defendant's prior or subsequent acts be similar in kind to the charged offens $\mathrm{e}^{157}$ effectively prevents the prosecution from introducing evidence of unrelated crimes that might result in the jury deciding that the defendant is a "bad man" who should be convicted merely for his past criminal behavior. The requirement that the charged or uncharged misconduct evidence be close in time to the charged offense ${ }^{158}$ has a similar effect.

Another criticism of the entrapinent defense is based on the standard of proof that is required to allow the imtroduction of a defendant's similar acts. The U.S. Supreme Court in Huddleston $v$. United States ${ }^{159}$ held that this was a question of conditional relevance governed by Rule 104(b); therefore, "[the similar act] evidence should be admitted if there is sufficient evidence to support a finding by the jury that the defendant committed the similar act."160 Many commentators, however, advocate a higher standard. $^{161}$ The main concern of commentators who oppose the standard enunciated by the Supreme Court and the Federal Rules of Evidence appears to be that the introduction of the similar act evidence creates the potential for unfair prejudice. ${ }^{162}$ As this Note has explained, however, the current evidentiary framework of the entrapment defense contains adequate safeguards to avoid unfair prejudice to the defendant that the introduction of uncharged misconduct evidence might cause. ${ }^{163}$

Critics of Huddleston also argue that the defendant's constitutional right to due process requires a higher standard of proof: ${ }^{164}$

157. See supra text accompanying notes $43-45$.

158. See supra text accompanying notes 46-51.

159. 485 U.S. 681 (1988).

160. Id. at 685 .

161. "[C]ourts should . . . require a greater standard for admissibility of other crimes evidence than sufficient to support a finding by a preponderance." Patterson, supra note 146 at 352; see also Charles V. Laughlin, Preliminary Questions of Fact: $A$ New Theory, 31 WASH. \& LEE L. REV. 285, 308-09 (1974) (suggesting that the judge must be satisfied that the defendant committed the uncharged misconduct before the evidence is admitted); Stephen A. Saltzburg, Standards of Proof and Preliminary Questions of Fact, 27 STAN. L. REV. 271 (1975) (proposing a balancing method based on a number of factors, such as whether the trial is civil or criminal, the type of preliminary question, and whether the question deals with an issue of reliability).

162. Lauglilin, supra note 161 , at 309 (noting "the drastic effect of confronting a defendant being tried for one offense with laving committed another"); Patterson, supra note 146, at 354 (noting "[t]he great potential for unjust damage to the defense").

163. See supra notes $150-158$ and accompanying text.

164. See Abraliam P. Ordover, Balancing the Presumption of Guilt and Innocence: 
"The Due Process Clause serves as the strongest constitutional hook froin which to hang a requirement of clear and convincing proof of the occurrence of the other crime." 165 This argument derives from the assurance that the defendant can only be convicted when the evidence proves his guilt beyond a reasonable doubt. ${ }^{166}$ Critics, however, have failed to point to any language in the Constitution or any common law precedent that would support the novel contention that a higher standard of proof is constitutionally mandated.

Indeed, even when the federal circuit courts of appeals were sphit on this issue, ${ }^{167}$ not one of the circuit courts that required a showing of clear and convincing proof claimed that such a requirement was constitutionally inandated. ${ }^{168}$ The Supreme Court's opinion in Huddleston and the approval of Rule 104(b) by legal scholars, Congress, and the Supreine Court strongly support the conclusion that the Constitution does not require a higher standard of proof. Additionally, in Lego v. Twomey, ${ }^{169}$ the Supreme Court held that the use of the preponderance standard to determine the admissibility of evidence in a criminal case did not violate the defendant's rights. ${ }^{170}$ The Court noted that there is a difference between the standard of proof used in admitting evidence and the standard of proof used in determining guilt or innocence. ${ }^{171}$ Thus, there is little doubt that the standard of proof announced in Huddleston and in Rule 104(b) is vahd and does not violate the Due Process Clause.

The third criticisin is that proof of the defendant's subsequent similar acts is irrelevant to a subjective evaluation of the defendant's predisposition. Commentators have argued specifically that subsequent act evidence to prove intent ${ }^{172}$ and knowl-

Rules 404(b), 608(b) and 609(a), 38 EMORY L.J. 135, 174 (1989) ("The assumption that a defendant can be afforded a fair trial under these conditions is dangerously wrong.").

165. Patterson, supra note 146 , at 359 .

166. In re Winship, 397 U.S. 358 (1970).

167. See supra text accompanying notes 53-55.

168. See, e.g., United States v. Leight, 818 F.2d 1297, 1302 (7th Cir.), cert. denied, 484 U.S. 958 (1987); United States v. Weber, 818 F.2d 14, 14-15 (8th Cir. 1987); United States v. Vaccaro, 816 F.2d 443, 452 (9th Cir.), cert. denied, 484 U.S. 928 (1987); United States v. Lavelle, 751 F.2d 1266, 1276 (D.C. Cir.), cert. denied, 474 U.S. 817 (1985).

169. 404 U.S. 477 (1972).

170. Id. at $486-87$.

171. Id.

172. See, e.g., Norman Krivosha et al., Relevancy: The Necessary Element in Using 
edge $^{173}$ is inadmissible because "[t]he state of one's mind at a subsequent time should not be admitted to establish the state of one's mind at a prior time."174 The rationale for the critics' proposed per se rule against the admissibility of subsequent act evidence relating to state of mind is that the evidence is irrelevant because a defendant's state of mind can change over time.

Although the premise that a defendant's state of mind can change over time is correct, the claim that it renders subsequent act evidence irrelevant and therefore inadınissible is unconvincing. The argument that a defendant's state of mind changes over timie would apply equally well to prior acts, but few cominentators have suggested that prior acts should be excluded on this ground. ${ }^{175}$ Since a defendant's prior acts and concurrent prior states of mind inake it inore likely that the defendant had the same state of mind at the time of the charged offense, the defendant's subsequent acts and subsequent states of mind also make it more likely that the defendant had the same state of inind at the time of the charged offense. Both types of conduct ineet the requirement of relevancy, ${ }^{176}$ and both should be admissible. ${ }^{177}$ Such acts are especially relevant in the context of an entrapinent defense. If a defendant truly lacked a predisposition to commit the illegal act, he would not be likely to repeat it once the government inducement was withdrawn. The defendant's continuation of the illegal activity after the inducement is removed strongly suggests that he was predisposed to engage in the illegal conduct.

Evidence of Other Crimes, Wrongs, or Bad Acts to Convict, 60 NEB. L. REV. 657, 672 (1981) ("[E]vidence that one was tempted to indulge in a criminal act or had a particular state of mind at a subsequent time cannot possibly establish either prior motive or intent.").

173. Id. at 674 ("[S]ubsequent acts showing knowledge are never admissible to prove prior knowledge.").

174. Id. at 672 .

175. Instead, inany commentators have suggested that prior acts inust be excluded because the jury values such evidence too highly, resulting in unfair prejudice to the defendant. For a more thorough discussion of this point, see supra text accompanying notes $144-47$.

176. " 'Relevant evidence' means evidence having any tendency to make the existence of any fact that is of consequence to the determination of the action more probable or less probable than it would be without the evidence." FED. R. EVID. 401.

177. FED. R. EVID. 402 states that "[a]ll relevant evidence is admissible except as otherwise provided by the Constitution of the United States, by Act of Congress, by these rules, or by other rules prescribed by the Supreme Court pursuant to statutory authority." There is no other rule or law that excludes subsequent similar acts. 


\section{B. Reputation Evidence}

Another major criticism of the present evidentiary rules used in the entrapment defense mvolves the use of the defendant's reputation to prove a criminal predisposition. This criticism closely parallels that of academics who condemn the use of similar act evidence. Critics offer two separate rationales to oppose the use of reputation evidence. First, they contend that the reputation evidence is unfairly prejudicial to the defendant. Second, they argue that the defendant will be forced to choose between forgoing the entrapment defense and having evidence of his reputation admitted into evidence to prove his predisposition.

Critics argue that the admission of reputation evidence is unfairly prejudicial. Their rationale is the same as that which academics who oppose the use of similar act evidence offer: ${ }^{178}$ that the jury may use the evidence of the defendant's reputation as proof of his guilt on the substantive crime. ${ }^{179}$ Those Supreme Court Justices who advocated the objective view of the entrapment defense often rehied on this same line of reasoning. ${ }^{180}$

The argument that the use of reputation evidence is unfair to the defendant is unpersuasive. As previously noted in the context of similar act evidence, ${ }^{181}$ the very nature of the entrapment defense effectively prevents the defendant from claiming that the prosecution's proof of his criminal predisposition unfairly prejudices him. By asserting that he was entrapped, the defendant implicitly admits that he committed the substantive crime; the claim that the jury may misuse reputation evidence is therefore a sham. ${ }^{182}$

178. See supra notes $144-47$ and accompanying text.

179. "The defendant may end up being judged not on the basis of the act for which the indictment was secured but for 'a general criminal depravity and wickedness." Maura F.J. Whelan, Coinment, Lead Us Not into (Unwarranted) Temptation: A Proposal to Replace the Entrapment Defense with a Reasonable-Suspicion Requirement, $133 \mathrm{U}$. PA. L. REV. 1193, 1207 (1985) (quoting Richard C. Donnelly, Judicial Control of Informants, Spies, Stool Pigeons, and Agent Provocateurs, 60 YALE L.J. 1091, 1108 (1951)).

180. Justice Stewart claimed that

[t]his sort of evidence is not only unreliable ... but it is also highly prejudicial, especially if the matter is submitted to the jury, for, despite instructions to the contrary, the jury may well consider such evidence as probative not simply of the defendant's predisposition, but of his guilt of the offense with which he stands charged.

United States v. Russell, 411 U.S. 423, 443 (1973) (Stewart, J., dissenting); see also Sherman v. United States, 356 U.S. 369, 382 (1958) (Frankfurter, J., concurring); Sorrells v. United States, 287 U.S. 435, 458 (1932) (Roberts, J., concurring).

181. See supra notes $150-53$ and accompanying text.

182. For a discussion of the likely outcome of a defendant's inconsistent claims that 
Additionally, the Federal Rules of Evidence provide that the jury must be given strict instructions regarding the permissible uses of the reputation evidence. ${ }^{183}$ Therefore, even if the question of the defendant's substantive guilt were still at issue, the jury would be instructed not to use reputation evidence to decide this issue. For these reasons, it is appropriate to admit evidence of a defendant's reputation to prove that the defendant had a criminal predisposition; the admission of such evidence is not unfairly prejudicial.

Critics of the use of reputation evidence also contend that allowing the prosecution to use reputation evidence to prove a defendant's criminal predisposition forces the defendant to either forgo the entrapment defense or to allow the jury to hear the allegedly prejudicial evidence. Those Supreme Court Justices who advocated an objective entrapment defense also used this argument. ${ }^{184}$ Since there is no "danger" of unfair prejudice when the defendant has implicitly admitted his guilt in asserting the entrapment defense, this rationale is no more persuasive than the first.

Assuming, arguendo, that such a danger did exist, there is still no compelling reason to limit the prosecution's use of reputation evidence. A defendant is often faced with unpalatable choices, outside the context of an entrapment defense, in presenting his defense. If a defendant wishes to testify, he opens the door to the introduction of evidence of his prior convictions ${ }^{185}$ and forfeits his right to avoid self-incrimination on those matters to which he decides to testify. ${ }^{186}$ When a defendant, or any other witness, tes-

he was either entrapped or that he did not engage in the prohibited conduct, see supra note 152 and accompanying text.

183. See FED. R. EVID. 105.

184. For example, Justice Frankfurter noted that

[t] he danger of prejudice in such a situation, particularly if the issue of entrapment must by submitted to the jury and disposed of by general verdict of guilty or innocent, is evident. The defendant must either forego the claim of entrapment or run the substantial risk that in spite of instructions, the jury will allow a ... bad reputation to weigh in its determination of guilt of the specific offense of which he stands charged.

Sherman, 356 U.S. at 382 (Frankfurter, J., concurring).

185. See FED. R. EVID. 609(a).

186. The defendant's decision to testify acts as a waiver of his right to avoid self-imcrimination.

The immunity from giving testimony is one which the defendant nay waive by offering himself as a witness. When he takes the stand in his own behalf, he does so as any other witness, and ... he niay be cross-examined as to the facts in issue .... His waiver is not partial; having once cast aside the cloak of immunity, he may not resune it at will, whenever cross-examination may be inconvenient or embarrassing. 
tifies, the jury has a right to know of the witness's prior convictions so that it may assess the reliability and truthfulness of the testimony. ${ }^{187}$ If the defendant testifies on his own behalf, the. government must be able to cross-examine him to verify the accuracy of lis testimony and to point out to the jury any inconsistencies. Similarly, once a defendant puts his own character or the character of the victim in issue, the prosecution may use character evidence in rebuttal, although such evidence is generally inadmissible. ${ }^{188}$ In all these cases, the defendant must make strategic decisions concernimg lis defense that, critics argue, force him either to suffer some prejudice or to forfeit a potential aid to his defense.

The only "prejudice" that a defendant suffers in having to nake such a decision, however, is that wlich results froin allowing the jury to hear evidence from both the prosecution and the defense, rather than an uncontested soliloquy of the defendant's assertions. The current evidentiary rules allow the jury to evaluate the evidence in a more informed inanner and weigh it more accurately. The entrapment defense should be no different. If the defendant claims he was not predisposed to commit the crime for which he is charged, the prosecution is entitled to rebut that claim with reputation evidence that indicates that the defendant was predisposed. By hearing both sides of the argument, the jury will be able to reach a fair and well-reasoned decision.

\section{CONCLUSION}

Since its inception, the entrapment defense has focused on a subjective evaluation of the defendant's predisposition. The focus of the predisposition inquiry is on the actions and intent of the individual defendant. This focus is appropriate because our criminal laws are based on the preimise that every person is accountable for those acts that he willingly commits. By focusing on each defendant's predisposition to commit the crime with which he is

Raffel v. United States, 271 U.S. 494, 496-97 (1926) (citations omitted).

187. Evidence of the defendant's prior convictions affects his credibility.

The rationale for admitting prior conviction evidence for impeachment purposes is that the jury should be informed about the character of a witness who asks the jury to believe his testimony. The record of prior convictions is considered indicative of the defendant's criminal nature which, in turn, suggests a propensity to falsify his testimony ....

United States v. Garber, 471 F.2d 212, 215 (5th Cir. 1972).

188. See FED. R. EVID. 404(a). 
charged, the entrapment defense protects from conviction those defendants who are not morally blameworthy and committed the offense only because they were induced to do so by the government.

Critics have argued that numerous changes in the Federal Rules of Evidence should be made to protect the criminal defendant who claims entrapment. Proposed changes imclude the exclusion of evidence of the defendant's reputation and the exclusion of evidence of the defendant's commission of similar acts. These proposed changes are without merit. Proof that the defendant committed acts similar to the crime with which he is currently charged and proof of his reputation are highly probative of his predisposition to commit the charged offense. The proposed changes would result in the release of many defendants who were not entrapped and would prohibit the government from introducing relevant and highly probative evidence of the defendant's criminal conduct. The entrapinent defense exists to protect from conviction only those defendants who, despite committing a criminal act, lacked moral blameworthiness. The current evidentiary rules serve this purpose by accurately and fairly separating blameworthy criminals from those who were wrongfully entrapped by government inducement. 
. 